\title{
CROSS SECTIONAL STUDY REVEALS A HIGH PERCENTAGE OF ASYMPTOMATIC Plasmodium vivax INFECTION IN THE AMAZON RIO NEGRO AREA, BRAZIL
}

\author{
Martha C. SUÁREZ-MUTIS(1), Patricia CUERVO(1), Fabiana M.S. LEORATTI(2), Sandra L. MORAES-AVILA(2), Antonio Walter FERREIRA(2), \\ Octavio FERNANDES(1) \& José Rodrigues COURA(1)
}

\begin{abstract}
SUMMARY
A parasitological, clinical, serological and molecular cross-sectional study carried out in a highly endemic malaria area of Rio Negro in the Amazon State, Brazil, revealed a high prevalence of asymptomatic Plasmodium vivax infection. A total of 109 persons from 25 families were studied in five villages. Ninety-nine inhabitants $(90.8 \%)$ had at least one previous episode of malaria. Serology showed $85.7 \%$ and $46.9 \%$ of positivity when $P$. falciparum antigens and P. vivax MSP-1, respectively, were used. Twenty blood samples were PCR positive for $P$. vivax (20.4\%) and no P. falciparum infection was evidenced by this technique. No individual presenting positive PCR reaction had clinical malaria during the survey neither in the six months before nor after, confirming that they were cases of asymptomatic infection. Only one 12 year old girl presented a positive thick blood smear for $P$. vivax. This is the first description of asymptomatic Plasmodium infection in this area studied.
\end{abstract}

KEYWORDS: Malaria; Asymptomatic infection; Plasmodium vivax; Brazilian Amazon.

\section{INTRODUCTION}

Clinical presentation of Plasmodium infection can vary from asymptomatic cases to fatal severe disease. Previous infection and immunity play a major role in defining the outcome of the disease. Symptomless malaria is commonly observed in high transmission areas in Africa and Southeast Asia, where transmission is very intense along the year and therefore individuals are continuously exposed to the parasite ${ }^{7,9,17}$. Although asymptomatic infections were described in the southern Brazilian State of Santa Catarina in 1971 caused by P. vivax, only in 1995 the first cases from the Brazilian Amazon, were reported among gold miners ${ }^{2,15}$. Recently, cases of healthy individuals infected with $P$. vivax and/or $P$. falciparum were reported in Rondônia, in the Amazon River basin and it was shown that autochthonous population, and not migrants, was responsible for the permanent endemicity of malaria in the area ${ }^{1,10}$.

In the Americas, control programs are based on opportune diagnostic and adequate treatment of clinical malaria cases ${ }^{8}$. Consequently, asymptomatic infection could be an important challenge for control ${ }^{12}$. In these scenarios, humans act as natural reservoirs of the parasite that can be easily disseminated by vectors ${ }^{23}$.

Barcelos is a district in the middle Rio Negro region, in the Amazonas State, Brazil, which is considered to be a highly endemic area for malaria. The average Annual Parasitic Index (API) in the last
10 years was 42.2 per 1000 inhabitants, and in some areas like the Rio Padauiri, the average of API was almost 400 per 1000 inhabitants. Fifty- three percent of the clinically diagnosed cases occur in individuals younger than 15 years. New cases are distributed along the year. Both, $P$. falciparum and $P$. vivax, are responsible for the infection in this area and Anopheles darlingi is the main vector.

In order to evaluate the continuous malaria transmission in the area and the role played by putative asymptomatic carriers, a clinical, serological and molecular cross-sectional study was performed in the area.

\section{MATERIALS AND METHODS}

Study area. Rio Padauiri is a left margin affluent of Rio Negro (Fig. 1). It is a large tropical humid forest area with an annual average temperature of $28{ }^{\circ} \mathrm{C}\left(20-38{ }^{\circ} \mathrm{C}\right)$ and annual pluviometer index of 2,286.2 $\mathrm{mm}$. In this specific area, five small villages can be found: Tapera, Acú-Acú, Acuquaia, Ararinha and Ararão (from 00¹141,3S, $64^{\circ} 04^{\prime} 42 \mathrm{~W}$ to $\left.00^{\circ} 30^{\prime} 19 \mathrm{~N}, 64^{\circ} 03^{\prime} 29 \mathrm{~W}\right)$. The population is composed of approximately 180 habitants, most of them involved in the collection of "piaçaba" (vegetal fiber). For most part of the year, male adults work in the "piaçabal areas" which are located in the middle of the jungle along the Rio Padauiri. During school vacations, women and their children come to the aforementioned region in order to help their husbands at work.

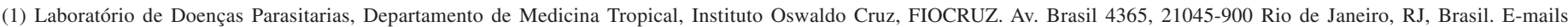
marmutis@ioc.fiocruz.br; patyce@ioc.fiocruz.br; octaviofernandes@fiocruz.br

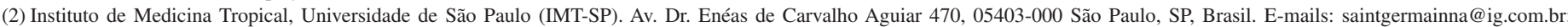
sands@usp.br; clawsmbf@usp.br

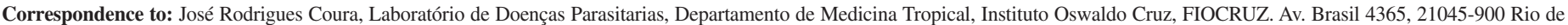
Janeiro, RJ, Brasil. Phone: (55 21) 2598 4339/4338 Ext. 206, Fax: (55 21) 2280 3740. E-mail: coura@ioc.fiocruz.br 

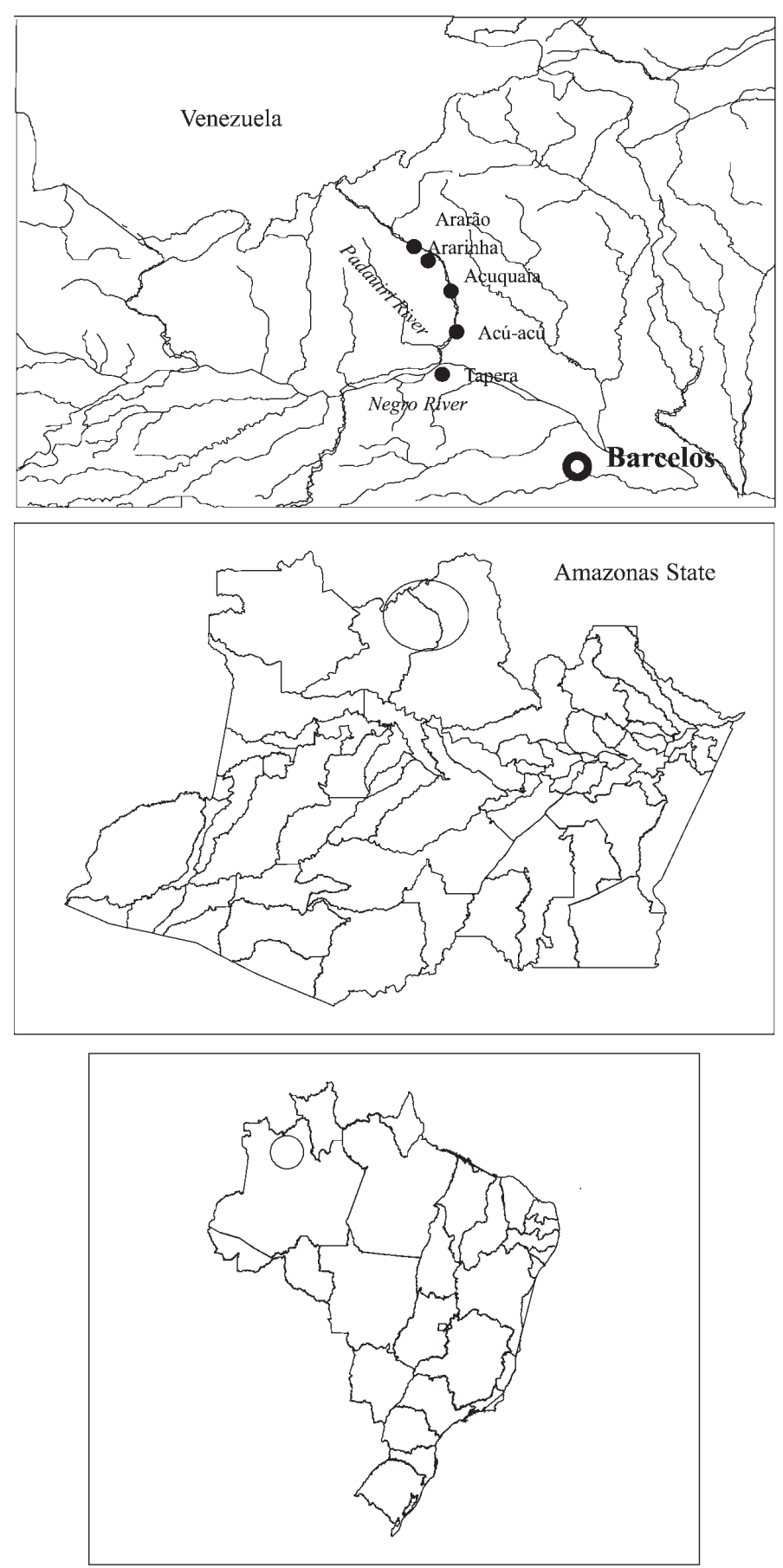

Fig. 1 - The study area was the Rio Padauiri (Barcelos District) in the Amazonas State in Brazil. The black dots show the small communities along the river: 1. Tapera, 2. Acú-acú, 3. Acuquaia, 4. Ararinha and 5. Ararão.

Study population. A parasitological, clinical and serological crosssectional study was carried out in 109 inhabitants from 25 families living in five villages at the Rio Padauiri area. After signing an informed consent form, the individuals answered a questionnaire about malaria antecedents and were then submitted to a clinical exam (temperature, pulse and blood pressure, liver and spleen examination). Blood samples were collected for malaria thick smear, serology and for polymerase chain reaction (PCR) looking for Plasmodium circulating DNA. Infants younger than two years old were excluded. Individuals with positive thick smear received standard antimalarial drugs in accordance with Malaria Control Program (Brazilian Ministry of Health). This study was approved by the Ethical Committee of the Fundação Oswaldo Cruz, Rio de Janeiro, Brazil.

Clinical malaria. Was considered when symptoms and signs were found with patent parasitemia verified by trained microscopists who examined 100 fields of stained thick blood smears at 1,000X magnification in field conditions (standardized technique from the Brazilian Ministry of Health).

Polymerase Chain Reaction (PCR). DNA was extracted from 300 $\mu \mathrm{L}$ of blood samples using the phenol/chloroform method and precipitated after the addition of sodium acetate and ethanol. Polymerase chain reactions (PCR) were performed according to SNOUNOU et al. after some minor modifications ${ }^{20,21}$. In brief, a species-specific region of the 18 rDNA of Plasmodium was amplified using a nested PCR protocol. All PCR amplifications were performed in $25 \mu \mathrm{L}$ volume containing $1.5 \mathrm{mM} \mathrm{MgCl}, 0.12 \mathrm{mM}$ dNTPs, $5 \mathrm{pmol}$ of each oligonucleotide and $0.5 \mathrm{U}$ of Taq polymerase (Invitrogen ${ }^{\circledR}$ ). In the first reaction, $3 \mu \mathrm{L}$ of extracted DNA were added, using pairs of primers targeting an outer region specific to the Plasmodium genus. One $\mu \mathrm{L}$ of the first reaction product was used as template in a second nested reaction in order to yield specific $P$. falciparum and $P$. vivax products. The temperature profile for the PCR was: five min at $95{ }^{\circ} \mathrm{C}$; 25 cycles of one min at $94{ }^{\circ} \mathrm{C}$, two min at $58{ }^{\circ} \mathrm{C}$, two min at $72{ }^{\circ} \mathrm{C}$; followed by the second reaction where the annealing temperature was modified to $65^{\circ} \mathrm{C}$ and the cycles repeated 30 times. The PCR products were visualized under UV light after $2 \%$ agarose gel electrophoresis in $0.5 \mathrm{X}$ Tris borate EDTA buffer and ethidium-bromide staining. A sample was considered positive if a 205 and/or 120 base-pair product (for $P$. falciparum and $P$. vivax, respectively) was detected. Twenty samples were amplified three times in order to verify the reproducibility of the assay. In every set of reactions, negative and positive controls were used (DNA extracted from patients presenting clinical malaria and patent parasitemia with $P$. falciparum and $P$. vivax).

Serological studies. Serum was obtained after proper centrifugation of collected blood and stored with Glycerine solution $1: 1$ at $4{ }^{\circ} \mathrm{C}$ in the area and then at $-20{ }^{\circ} \mathrm{C}$ until use. IgG antibodies were detected by ELISA using as antigens Zwittergent-extracted blood stage of $P$. falciparum and $P$. vivax $\mathrm{MSP}_{19}$ recombinant protein (kindly donated by Dr. Irene Soares). The results were expressed in Reactivity Index (RI) that is the ratio between the mean Optic Density (OD) of the sample and the OD of the "cut-off". The cut-off was calculated as the mean OD plus two standard deviations of six negative results for each plate ${ }^{3,4}$. Serum samples with a RI equal to or greater than one were considered positive and used for the definition of the functional affinity of IgG. For these studies, sera were incubated in duplicate. One of the duplicates was washed for five minutes with $8 \mathrm{M}$ urea solution after serum incubation and the other duplicate was washed with PBS. The avidity index (AI) was calculated as the fraction of the OD of the sample treated with urea and that of the untreated sample, multiplied by 100 . An AI below $30 \%$ corresponds to low avidity antibodies; AI between 30 and $50 \%$ to an intermediate avidity 


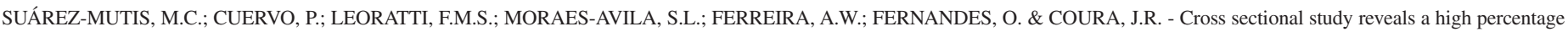
of asymptomatic Plasmodium vivax infection in the Amazon Rio Negro area, Brazil. Rev. Inst. Med. trop. S. Paulo, 49(3): 159-164, 2007.

Table 1

Distribution of inhabitants by residence locality, antecedents of previous malaria clinical episodes, and comparison between thick smear and PCR results in a 98 subsamples of five villages along the Rio Padauiri

\begin{tabular}{|c|c|c|c|c|c|c|c|c|c|c|}
\hline & \multicolumn{2}{|c|}{ Population } & \multicolumn{4}{|c|}{ Previous malaria } & \multicolumn{2}{|c|}{ Thick smear } & \multicolumn{2}{|c|}{ PCR } \\
\hline & Number & $\%$ & Yes & $\%$ & Not & $\%$ & Pos & $\%$ & Pos & $\%$ \\
\hline Tapera & 31 & 28.4 & 29 & 93.5 & 2 & 6.9 & $1 / 27$ & 1 & $4 / 27$ & 14.8 \\
\hline Acú-Acú & 22 & 20.2 & 17 & 77.3 & 5 & 22.7 & $0 / 18$ & 0 & $4 / 18$ & 22.2 \\
\hline Acuquaia & 29 & 26.6 & 27 & 93.1 & 2 & 6.9 & $0 / 31$ & 0 & $1 / 31$ & 3.2 \\
\hline Ararinha & 17 & 15.6 & 16 & 94.1 & 1 & 5.9 & $0 / 15$ & 0 & $9 / 15$ & 60 \\
\hline Ararão & 10 & 9.2 & 10 & 100.0 & 0 & 0.0 & $0 / 7$ & 0 & $2 / 7$ & 28.6 \\
\hline Total & 109 & 100.0 & 99 & 90.8 & 10 & 9.2 & $1 / 98$ & 1.02 & $20 / 98$ & 20.4 \\
\hline
\end{tabular}

and $\mathrm{AI}$ greater than $50 \%$ to high avidity. High avidity $\mathrm{IgG}$ antibodies indicate past infection, while low and intermediate avidity IgG antibodies might indicate recent infection ${ }^{4,14}$.

Statistical analysis. The EpiInfo 6.02 package (Centers for Diseases Control, Atlanta) version 6.02 was used for the statistical analysis. Proportions and categorical data were compared by the chisquare test $\left(\chi^{2}\right)$, with Mantel Haenszel correction, in cases of $2 \times 2$ contingency tables, or by Fisher's exact test. A confidence level of $95 \%$ was used.

\section{RESULTS}

All the 109 studied individuals live along the Rio Padauiri in five small villages. Residence distribution is shown in Table 1. The age of individuals enrolled into the study ranged between three to 79 years old $($ mean $=24$ years old, standard deviation $=18.6)$; gender and age groups distribution are shown in Table 2. Only one individual (1/109) was born outside the Amazonian region.

Malaria antecedents. Ninety-nine inhabitants (99/109-90.8\%) described at least one previous malaria episode. Fifty-two of the affected people were men comprising $98.1 \%(52 / 53)$ of the whole male sample and 47 were women corresponding to a total of $83.9 \%(47 / 56)$ of the female sample.

Previous malaria (42/48 - 87.5\%) was described in 42 individuals below the age of 15 and in 57 above this age (57/61 - 93.5\%). Among the first group ( $<15$ years), the average of previous malaria cases was

Table 2

Distribution of inhabitants by age groups and sex

\begin{tabular}{lccccc}
\hline $\begin{array}{l}\text { Age groups } \\
\text { distribution }\end{array}$ & \multicolumn{2}{c}{ Male } & \multicolumn{2}{c}{ Sex } & \multicolumn{2}{c}{ Total } \\
& $\mathrm{N}$ & $\%$ & $\mathrm{~N}$ & $\%$ & \\
\hline < 5 years & 2 & 28.6 & 5 & 71.4 & 7 \\
5-14 years & 18 & 43.9 & 23 & 56.1 & 41 \\
15-44 years & 22 & 51.2 & 21 & 48.8 & 43 \\
45-59 years & 7 & 63.6 & 4 & 36.4 & 11 \\
$\geq 60$ years & 4 & 57.1 & 3 & 42.9 & 7 \\
\hline Total & 53 & 48.6 & 56 & 51.4 & 109 \\
\hline
\end{tabular}

2.5 (one to six episodes) while in the second cluster ( $\geq 15$ years) the average was six (one to 50 episodes).

There was no statistically significant association between the description of previous malaria and specific professional profiles. Table 1 summarizes results of distribution of residence locality and previous malaria episodes.

In the six months prior to the study, $18.7 \%$ of the individuals $<15$ $(9 / 48)$ and $3.3 \%$ of the adults with 15 or more years of age (2/61) reported malaria episodes. The probability of having had malaria in the last six months was 6.8 higher in those $<15$ years than in the adult group $\left(\chi^{2}=7.02, p<0.05\right)$.

When inquired about malaria transmission mechanism, $42.6 \%$ of inhabitants with 15 years old or more (26/61) manifested to know how malaria is transmitted; however when we tried to establish knowledge level, only $13.1 \%(8 / 61)$ knew that malaria is a vector-borne disease. There was no correlation between people who reported malaria in the past and knowledge about transmission.

Physical exam. The physical exam revealed that $10.1 \%$ of inhabitants had palpable spleen and $23.8 \%$ had enlarged liver. The distribution of clinical anemia was the same for both age groups, $22.9 \%$ (11/48 of those $<15$ years and $14 / 61$ of adults). Splenomegaly was detected in $8.3 \%(4 / 48)$ and $11.5 \%$ (7/61) of the individuals $<15$ years and adults, respectively. No statistically significant difference was observed between these groups. During the survey, two inhabitants were found febrile however, when both thick smear and PCR analysis were carried out, the results were negative for Plasmodium parasites. Furthermore, neither had malaria six months before or after the study. A 12-year-old girl had a positive P. vivax thick blood smear. Despite the fact that this patient presented a positive parasitological test, neither fever nor other malaria symptoms were reported in the two weeks preceding the laboratory exam.

Serological results. From 109 individuals enrolled in the study, 98 blood samples were collected for serology. Serological results were positive for $85.7 \%$ (84/98) of samples when $P$. falciparum antigen was used (Table 3 ). The probability of a positive RI- $P f$ was 7.7 higher in individuals above the age of 15 than in younger individuals, with statistically significant difference $\left(\chi^{2}=10.78 ; p<0.05\right)$. The serology using $P$. vivax recombinant antigen $\left(\mathrm{MSP}_{19}-\mathrm{Pv}\right)$ revealed $46.9 \%$ 


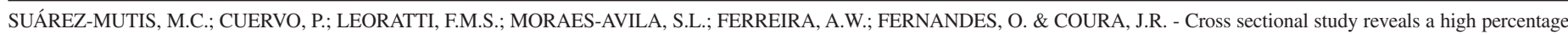
of asymptomatic Plasmodium vivax infection in the Amazon Rio Negro area, Brazil. Rev. Inst. Med. trop. S. Paulo, 49(3): 159-164, 2007.

Table 3

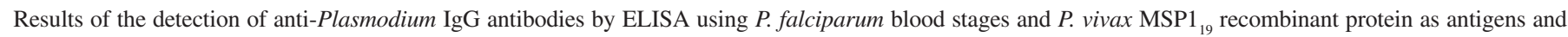
distribution of high and low/ intermediate $\operatorname{IgG}$ antibodies avidity by age groups

\begin{tabular}{|c|c|c|c|c|}
\hline \multirow[b]{2}{*}{ Antibodies } & & \multicolumn{3}{|c|}{ AGE GROUPS } \\
\hline & & $<15$ years old & $\geq 15$ years old & Total \\
\hline \multirow[t]{4}{*}{ anti-P. vivax MSP1 $_{19}$} & Negative & $27(71 \%)$ & $25(41.7 \%)$ & $52(53.1 \%)$ \\
\hline & $1-2$ & $9(23.7 \%)$ & $16(26.7 \%)$ & $25(25.5 \%)$ \\
\hline & $>2$ & $2(5.3 \%)$ & $19(31.6 \%)$ & $21(21.4 \%)$ \\
\hline & Total & $38(38.8 \%)$ & $60(61.2 \%)$ & $98(100 \%)$ \\
\hline \multirow[t]{4}{*}{ Anti-P. falciparum } & Negative & $3(10 \%)$ & $11(16.2 \%)$ & $14(14.3 \%)$ \\
\hline & $1-2$ & $8(26.7 \%)$ & $7(10.3 \%)$ & $15(15.3 \%)$ \\
\hline & $>2$ & $19(63.3 \%)$ & $50(73.5 \%)$ & $69(70.4 \%)$ \\
\hline & Total & $30(30.6 \%)$ & $68(69.4 \%)$ & $98(100 \%)$ \\
\hline \multicolumn{5}{|c|}{ P. falciparum IgG antibodies avidity (only if $P f$ IR $\geq 1$ ) } \\
\hline \multirow{2}{*}{\multicolumn{2}{|c|}{ Low or intermediate $(\mathrm{AI}<50 \%)$}} & $16(59.2 \%)$ & $17(29.9 \%)$ & $33(39.3 \%)$ \\
\hline & & $11(40.8 \%)$ & $40(70.1 \%)$ & $51(60.7 \%)$ \\
\hline \multicolumn{2}{|l|}{ Total } & $27(100 \%)$ & $57(100 \%)$ & $84(100 \%)$ \\
\hline
\end{tabular}

$\mathrm{RI}=$ Reactivity index; $\mathrm{AI}=$ avidity index

positivity (Table 3 ). The probability of a positive RI- $P v$ was 3.44 higher in individuals older than 15 years old than in younger individuals with statistically significant difference $\left(\chi^{2}=7.98 ; p=<0.05\right)$. The results for AI index of $\mathrm{IgG}$ positive RI-P. falciparum samples (84/98), are presented in Table 3. Briefly, 59.2\% individuals $<15$ years old and $29.8 \%$ of adults had low or intermediate avidity IgG antibodies, implying in recent malaria.

The probability of low or intermediate AI was 3.4 higher in individuals $<15$ years old than in individuals older than 15 years, with a statistically significant difference $\left(\chi^{2}=6.58 ; p<0.05\right)$. Among individuals who had malaria in the year previous to the study, the probability to have a low or intermediate AI was 3.76 higher than people who had malaria before $2002\left(\chi^{2}=4.35, p<0.05\right)$. When sex groups were compared, no differences were observed.

PCR results. Detection of Plasmodium parasites by PCR DNA amplification showed that $20.4 \%$ (20/98) samples were positive for $P$. vivax. No specific fragment for $P$. falciparum parasites was detected in the tested samples. Comparison between thick smear and PCR results is presented in Table 1. Relation between positive PCR for P. vivax and locality of residence of inhabitants is shown in Table 5. Briefly, $50 \%(11 / 22)$ of the individuals who lived in the village Ararinha-Ararão area were positive for $P$. vivax. The probability to have a positive PCR was 7.4 higher in individuals who live in Ararinha-Ararão region than in people who live in other villages. This difference was statistically significant $\left(\chi^{2}=15.14 ; p<0.05\right)$. There was no correlation between age or sex groups and positive PCR reaction. A PCR-negative sample has never been positive by light microscopy. Individuals with positive PCR for $P$. vivax did not have clinical malaria six months before neither after the survey. One hundred percent of reproducibility was achieved after comparison of the results of the twenty samples that were amplified three times.

\section{DISCUSSION}

The Rio Padauiri is characterized by piaçaba extractive activities; male adolescents and adults live in those working areas part of year while women and children stay in the villages during school time and go to the piaçaba places during school vacations. Ninety nine percent of the inhabitants are natural from the Amazonas State with a very high internal migration rate in order to go to the piaçaba working places. There are at least five affluents in middle Negro region where people are dedicated to extractivist activities.

This is the first study regarding the topic in the region. No published record of malaria epidemiology from this area was found. This knowledge will enable us to find the best strategies to control malaria in these populations. The Rio Padauiri region is a high transmission area with a very complex epidemiology. More than ninety percent of the inhabitants reported malaria in the past and this is confirmed by a high positivity for anti- $P$. falciparum IgG antibodies (RI- $P f=85.7 \%)$. Although serology is not a conclusive diagnosis of patent malaria, population studies have shown $P$. falciparum antibodies (RI- $P f$ ) to be more reactive and to present cross-reaction with $P$. vivax antigens in high transmission areas. The presence of low and intermediate avidity $\mathrm{IgG}$ antibodies have been correlated with recent infection ${ }^{14}$. Our findings showed that people who had a recent clinical malaria episode had a higher frequency of low or intermediate avidity IgG antibodies. Fifty nine percent of individuals younger than 15 years old presented low and intermediate avidity IgG anti-Plasmodium falciparum showing that the probability of a recent infection is higher for children than for adults.

In an intense transmission area like the Rio Padauiri, it is possible that adults acquire different grades of immunity and therefore become ill less frequently than children. Nevertheless, the probability of a Plasmodium infection is the same for both groups; this is further 


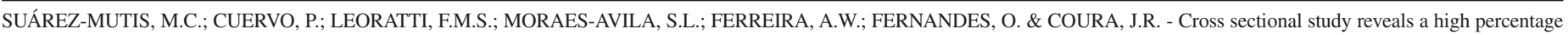
of asymptomatic Plasmodium vivax infection in the Amazon Rio Negro area, Brazil. Rev. Inst. Med. trop. S. Paulo, 49(3): 159-164, 2007.

reinforced by the inexistence of statistically significant differences in PCR results between children and adults. DRUILHE \& PERIGNON showed that in highly endemic areas, natural immunity needs permanent long time exposition to be acquired; also, natural immunity protects against malaria clinical episodes but it does not avoid malaria infection ${ }^{13}$. This state of immunity is denominated "premunition", and can be acquired after years of continuous exposition to the parasite; it is characterized by asymptomatic Plasmodium infection with subpatent parasitemia. The time taken for a child to acquire clinical immunity depends on the intensity of transmission, the parasite genetic diversity and the maturity of the host immune system ${ }^{5,22}$.

High transmission conditions are verified in Africa and clinical behavior of Plasmodium - particularly P. falciparum - infection is better established there ${ }^{6,23}$. In America this phenomenon is relatively new. In spite of the small number of studies, in recent years various researchers have reported more evidences of asymptomatic Plasmodium infection in Latin America ${ }^{1,10,11,16,19}$. ALVES et al. showed the existence of $P$. falciparum and $P$. vivax asymptomatic infection in riverine communities in Rondônia ${ }^{1}$. It was more frequent among adults.

In this study, distinct risks for acquiring malaria were verified according to the sites. Ararinha and Ararão are located very near the indigenous area where malaria is endemic. Coincidently the piaçaba gathering places are located in the surroundings of this area. This preliminary information leads us to think that infection takes place where men spend much of their time - in their working areas. This issue still needs further analyses.

We only found a twelve year-old child with $P$. vivax positive thick blood smear. Although thick blood smear is the gold standard for malaria diagnosis, this method lacks sensitivity for detecting asymptomatic Plasmodium infections in areas where people become immune presenting low parasitaemia ${ }^{18,20,21,24}$. Different studies showed that molecular diagnosis by PCR is more sensitive than the blood thick smear, particularly for detecting low parasite infections ${ }^{1}$. Our results showed that PCR reactions were positive in $20.4 \%$ of studied population; all of them characterized as $P$. vivax asymptomatic infections.

These results do not allow us to differentiate between (1) a fluctuant long time persistence of low parasitemia, which occasionally reach detection levels for a blood thick smear, and (2) a short time infection followed by parasite elimination ${ }^{7}$. To elucidate these hypotheses, new longitudinal studies are required ${ }^{1}$.

High degrees of asymptomatic Plasmodium infection may be a common theme in the Amazon and it has important implications on the planning of human activities (hydroelectric power plant, gas and oil projects, highways, rural settlements, etc.) in areas which require the influx of non-immune individuals.

\section{RESUMO}

Estudo seccional revela um alto percentual de infecção assintomática por Plasmodium vivax em área do Rio Negro, Amazonas, Brasil

Um estudo seccional parasitológico, clínico, sorológico e molecular, realizado em uma área altamente endêmica para malária, no Rio Negro, Estado do Amazonas, revela alta prevalência de infecção assintomática por Plasmodium vivax. Um total de 109 pessoas de 25 famílias residentes em cinco comunidades do Rio Padauiri, afluente do Rio Negro, foram estudadas. Noventa por cento dos habitantes $(90,8 \%)$ tinham tido pelo menos um episodio prévio de malária. A sorologia mostrou $85,7 \%$ e $46,9 \%$ de positividade quando antígenos de $P$. falciparum e $P$. vivax MSP-1, foram respectivamente usados. Vinte amostras de sangue submetidas ao PCR foram positivas para $P$. vivax (20,4\%), entretanto, nenhuma foi positiva para o $P$. falciparum por esta técnica. Nenhum paciente com PCR positivo durante o inquérito e seis meses antes ou depois teve manifestações clínicas de malária, portanto, podemos afirmar que eram assintomáticos. Somente uma criança de 12 anos de idade teve gota espessa positiva para $P$. vivax. Esta é a primeira descrição de infecção assintomática por Plasmodium na área estudada.

\section{ACKNOWLEDGEMENTS}

We are grateful to all residents of Rio Padauiri for their help and cooperation with the study, to Health National Foundation (FUNASA), in Barcelos and Manaus for advice on the conduction of the study and to Dr. Fabio Alves por English revision.

Financial support: This work was supported by PAPES (FIOCRUZ), CNPq (National Research Council in Brazil) and IAEA (International Atomic Energy Agency).

\section{REFERENCES}

1. ALVES, F.P.; DURLACHER, R.R.; MENEZES, M.J. et al. - High prevalence of asymptomatic Plasmodium vivax and Plasmodium falciparum infections in native Amazonian populations. Amer. J. trop. Med. Hyg., 66: 641-648, 2002.

2. ANDRADE, A.L.S.S.; MARTELLI, C.M.T.; OLIVEIRA, R.M. et al. - High prevalence of asymptomatic malaria in gold mining areas in Brazil. Clin. infect. Dis., 20: 475, 1995.

3. AVILA, S.L.M.; LEANDRO, M.C.; CARVALHO, N.B. et al. - Evaluation of different methods for Plasmodium detection in well defined population groups in an endemic area of Brazil. Rev. Inst. Med. trop. S. Paulo, 36: 157-162, 1994.

4. ÁVILA, S. \& FERREIRA, A.W. - Malaria diagnosis: a review. Braz. J. med. biol. Res., 29: 431-443, 1996

5. BAIRD, J.K.; JONES, T.R.; DANUDIRGO, E.W. et al. - Age dependent acquired protection against Plasmodium falciparum in people having two years exposure to hyperendemic malaria. Amer. J. trop. Med. Hyg., 45: 65-76, 1991.

6. BLOLAND, P.; BORIGA, D.A.; RUEBUSH, T.K. et al. - Longitudinal cohort study of the epidemiology of malaria infections in an area of intense malaria transmission. II. Descriptive epidemiology of malaria infection and disease among children. Amer. J. trop. Med Hyg., 60: 641-648, 1999.

7. BOTTIUS, E.; GUANZIROLLI, A.; TRAPE, J.F. et al. - Malaria: even more chronic in nature than previously thought; evidence for subpatent parasitaemia detectable by the polymerase chain reaction. Trans. roy. Soc. trop. Med. Hyg., 90: 15-19, 1996.

8. BOULOS, M. - Malária. Rev. Med. (S. Paulo), 79: 1-11, 2000.

9. BRUCE, M.C.; GALINSKI, M.R.; BARNWELL, J.W. et al. - Genetic diversity and dynamics of Plasmodium falciparum and $P$. vivax populations in multiply infected children with asymptomatic malaria infections in Papua New Guinea. Parasitology, 121: $257-272,2000$ 
SUÁREZ-MUTIS, M.C.; CUERVO, P.; LEORATTI, F.M.S.; MORAES-AVILA, S.L.; FERREIRA, A.W.; FERNANDES, O. \& COURA, J.R. - Cross sectional study reveals a high percentage of asymptomatic Plasmodium vivax infection in the Amazon Rio Negro area, Brazil. Rev. Inst. Med. trop. S. Paulo, 49(3): 159-164, 2007.

10. CAMARGO, E.P; ALVES, F. \& SILVA, L.H.P. - Symptomless Plasmodium vivax infections in native Amazonians. Lancet, 353: 1415-1416, 1999.

11. CAMARGO, L.M.A.; NORONHA, E. \& SALCEDO, J.M.V. - The epidemiology of malaria in Rondonia (Western Amazonia region, Brazil): study of a riverine population. Acta trop., 72: 1-11, 1999.

12. COURA, J.R.; SUÁREZ-MUTIS, M. \& LADEIA-ANDRADE, S. - A new challenge for malaria control in Brazil: asymptomatic Plasmodium infection. A review. Mem. Inst. Oswaldo Cruz, 101: 229-237, 2006

13. DRUILHE, P. \& PERIGNON, J.L. - Mechanisms of defense against $P$. falciparum asexual blood stages in humans. Immunol. Lett., 41: 115-120, 1994.

14. FROTA, C.; FONTES, E.; BICHAT, R. \& FERNANDES, O. - Application of antitoxoplasmosis IgG antibodies avidity test. J. bras. Pat. med. lab., 37: 98-99, 2001.

15. JONES, S.A. \& FERREIRA, NETO, J.A. - Symptomless Plasmodium vivax parasitaemias and malaria eradication in Santa Catarina State, Brazil. Rev. Soc. bras. Med. trop., 5: $21-35,1971$

16. MARCANO, T.J.; MORGADO, A.; TOSTA, C.E. \& COURA, J.R. - Cross-sectional study defines difference in malaria morbidity in two Yanomami communities on Amazonian boundary between Brazil and Venezuela. Mem. Inst. Oswaldo Cruz, 99: 369-376, 2004.

17. OWUSU-AGYEI, S.; SMITH, T.; BECK, H.P.; AMENGA-ETEGO, L. \& FELGER, I. Molecular epidemiology of Plasmodium falciparum infections among asymptomatic inhabitants of a holoendemic malarious area in northern Ghana. Trop. Med. Int. Hlth, 7: 421-428, 2002
18. ROPER, C.; ELHASSAN, I.M.; HVIID, L. et al. - Detection of very low level Plasmodium falciparum infections using the nested PCR and a reassessment of the epidemiology of unstable malaria in Sudan. Amer. J. trop. Med. Hyg., 54: 325-331, 1996.

19. ROSHANVARAN, B.; KARI, E.; GILMAN, R.H. et al. - Endemic malaria in the peruvian Amazon region of Iquitos. Amer. J. trop. Med. Hyg., 69: 45-52, 2003.

20. SNOUNOU, G.; VIRIYAKOSOL, S.; ZHU, X.P. et al. - High sensitivity of detection of human malaria parasites by use of nested polymerase chain reaction. Molec. Biochem. Parasit., 61: 315-320, 1993.

21. SNOUNOU, G. - Detection and identification of the four malaria parasite species infecting humans by PCR amplification. Meth. molec. Biol., 50: 263-291, 1996.

22. SNOW, R.W. \& MARSH, K. - New insights into the epidemiology of malaria relevan for disease control. Brit. med. Bull., 54: 293-309, 1998.

23. TRAPE, J.F.; ROGIER, C.; KONATE, L. et al. - The Dielmo Project: a longitudinal study of natural malaria infection and the mechanisms of protective immunity in a community living in a holoendemic area of Senegal. Amer. J. trop. Med. Hyg., 51: 123-137, 1994.

24. URDANETA, L.; GUEVARA, P. \& RAMIREZ, J.L. - Evaluation of DNA recombinan methodologies for the diagnosis of Plasmodium falciparum and their comparison with the microscopy assay. Mem. Inst. Oswaldo Cruz, 93: 639-646, 1998.

Received: 7 March 2006

Accepted: 16 November 2006 